\title{
Mechanistic investigation of toxicity of chromium oxide nanoparticles in murine fibrosarcoma cells
}

\author{
This article was published in the following Dove Press journal: \\ International Journal of Nanomedicine \\ 29 March 2016 \\ Number of times this article has been viewed
}

\section{Saud Alarifi \\ Daoud Ali \\ Saad Alkahtani}

Department of Zoology, College of Science, King Saud University, Riyadh, Saudi Arabia
Correspondence: Daoud Ali

Department of Zoology, College of Science, King Saud University, Box 2455, Riyadh II45I, Saudi Arabia Tel +96655890 462।

Fax+966 II 46785 I4

Email daudali.ksul2@yahoo.com; aalidaoud@ksu.edu.sa

\begin{abstract}
Chromium oxide nanoparticles $\left(\mathrm{Cr}_{2} \mathrm{O}_{3} \mathrm{NPs}\right)$ are widely used in polymers and paints. In the present study, we aimed to determine the toxicity of $\mathrm{Cr}_{2} \mathrm{O}_{3} \mathrm{NPs}$ in murine fibrosarcoma (L929) cells. The cytotoxicity of $\mathrm{Cr}_{2} \mathrm{O}_{3}$ NPs was measured by MTT and neutral red uptake assays; $\mathrm{Cr}_{2} \mathrm{O}_{3} \mathrm{NPs}$ had significant cytotoxic effects on L929 cells. Enhancement of intracellular reactive oxygen species was observed in L929 cells after exposure to $\mathrm{Cr}_{2} \mathrm{O}_{3} \mathrm{NPs}$. $\mathrm{Cr}_{2} \mathrm{O}_{3} \mathrm{NPs}$ produced caspase- 3 , indicating that exposure to $\mathrm{Cr}_{2} \mathrm{O}_{3} \mathrm{NPs}$ induced apoptosis. After exposure to $\mathrm{Cr}_{2} \mathrm{O}_{3} \mathrm{NPs}$, the cellular glutathione level decreased and lipid peroxidation, superoxide dismutase, and catalase increased in a dose- and time-dependent manner. By using single-cell gel tests, we also observed increased DNA damage in $\mathrm{Cr}_{2} \mathrm{O}_{3} \mathrm{NP}$ exposure-duration- and dose-dependent fashion. Cell toxicity and DNA damage may be useful biomarkers for determining the safety of $\mathrm{Cr}_{2} \mathrm{O}_{3} \mathrm{NPs}$ in human and animal health.
\end{abstract}

Keywords: $\mathrm{Cr}_{2} \mathrm{O}_{3} \mathrm{NPs}$, L929 cells, MTT assay, oxidative stress

\section{Introduction}

Engineered nanoparticles are extensively used in the industrial sector. Chromium oxide nanoparticles $\left(\mathrm{Cr}_{2} \mathrm{O}_{3} \mathrm{NPs}\right)$ are used in pigments, thermal protection coating, and sensing of humidity. ${ }^{1,2}$ It has been reported that interaction of nanoparticles with biological molecules depends on their shape and size. ${ }^{3,4}$ To use nanoparticles for therapeutic applications, it is important to assess their toxicity in cancer cells and normal cells. Nanoparticles can induce effects that are harmful to human health, specifically depending on the particle size. ${ }^{5}$ Warheit et $\mathrm{al}^{6}$ and Oberdorster et $\mathrm{al}^{7}$ reported that oxidative stress and inflammation occur in animals upon inhalation of nanoparticles. The toxic effects of $\mathrm{Cr}_{2} \mathrm{O}_{3}$ NPs (eg, DNA damage) are of specific concern because alterations in genetic materials have the potential to cause cell death, cancer, and adverse reproductive effects. The comet assay is a widely accepted technique used to determine the genotoxicity of xenobiotic compounds in living organisms and to determine the toxic potential of different doses of carcinogens or genotoxic materials in animals. ${ }^{8}$ In vitro examinations have validated the physiological response to nanoparticles in animals and furnished results demonstrating increased oxidative stress in nanoparticle-treated cell lines. ${ }^{9,10}$

The present study was conducted to assess the toxicity of $\mathrm{Cr}_{2} \mathrm{O}_{3} \mathrm{NPs}$ in murine fibrosarcoma (L929) cells. We measured levels of reactive oxygen species (ROS), superoxide dismutase (SOD), glutathione (GSH), and malondialdehyde (MDA) in L929 cells in response to $\mathrm{Cr}_{2} \mathrm{O}_{3}$ NPs. DNA damage effects were evaluated using the comet assay. 


\section{Materials and methods}

\section{Chemicals and reagents}

$\mathrm{Cr}_{2} \mathrm{O}_{3} \mathrm{NPs} ; 2^{\prime}, 7^{\prime}$-dichlorofluorescin diacetate (DCFH-DA); 5,5'-dithiobis(2-nitrobenzoic acid) and GSH were acquired from Sigma-Aldrich (St Louis, MO, USA).

\section{Characterization of $\mathrm{Cr}_{2} \mathrm{O}_{3} \mathrm{NPs}$}

$\mathrm{Cr}_{2} \mathrm{O}_{3} \mathrm{NP}$ was suspended in culture media $(1 \mathrm{mg} / \mathrm{mL})$ and dispersed by using a sonicator for 20 minutes with $40 \mathrm{~W}$ power, at normal temperature. Size and shape characterization of $\mathrm{Cr}_{2} \mathrm{O}_{3}$ NPs was studied using high-resolution transmission electron microscope (HRTEM). Size of $\mathrm{Cr}_{2} \mathrm{O}_{3} \mathrm{NP}$ in DMEM was examined by using dynamic light scattering (DLS) (Nano-Zeta Sizer-HT, Malvern Instrument, Malvern,UK).

\section{L929 cell culture and treatment}

Murine fibrosarcoma (L929) cell line was obtained from American Type Culture Collection (Rockville, MD, USA). L929 cells with $80 \%$ growth were collected and cultured into 96-well plates and petri dishes. We treated L929 cells to various doses $(0,10,50$, and $100 \mu \mathrm{g} / \mathrm{mL})$ for 12 and 24 hours.

\section{Morphological analysis of cells}

Morphology of L929 cell lines were seen under an inverted microscope (Leica DMIL, Leica Microsystem, Wetzlar, Germany) after $\mathrm{Cr}_{2} \mathrm{O}_{3}$ NPs treatment for 24 hours.

\section{MTT assay}

Viability of L929 cells was assessed after treatment of $\mathrm{Cr}_{2} \mathrm{O}_{3} \mathrm{NP}$ by MTT assay. ${ }^{11}$ Cell viability was calculated using the following formula:

$$
\underset{\text { viability }(\%)}{\text { Cell }}=\frac{\text { OD exposed cells }- \text { OD of blank }}{\text { OD of control }- \text { OD of blank }} \times 100
$$

\section{NRU assay}

Viability of L929 cells after treatment of $\mathrm{Cr}_{2} \mathrm{O}_{3} \mathrm{NP}$ for 12 and 24 hours was assessed by neutral red uptake (NRU) assay. ${ }^{12}$

\section{Measurement of ROS generation}

Generation of ROS was measured in L929 cells after exposure of $\mathrm{Cr}_{2} \mathrm{O}_{3}$ NPs for 12 and 24 hours using DCFH-DA dye. ${ }^{13}$

\section{Measurement of oxidative biomarkers}

L929 cells $\left(\sim 6 \times 10^{6}\right)$ were grown in a flask $\left(75 \mathrm{~cm}^{2}\right)$ and administered $\mathrm{Cr}_{2} \mathrm{O}_{3} \mathrm{NPs}(0,10,50$, and $100 \mu \mathrm{g} / \mathrm{mL})$ for 12 and 24 hours. Exposed L929 cells were collected and washed with chilled phosphate-buffered saline. The collected cells were lysed with a lysing solution. The cells and the lysing solution were cryocentrifuged at $10^{4} \times g$ for 10 minutes at $4^{\circ} \mathrm{C}$, following which they were placed on ice for oxidative stress. Protein content in cell lysate was determined by using Lowry et al's method. ${ }^{14}$

Lipid peroxide (LPO) was evaluated by estimating the production of MDA. ${ }^{15}$ SOD level was measured according to Alarifi et al's method. ${ }^{16} \mathrm{GSH}$ level was evaluated by using Elman's methods. ${ }^{17}$

\section{Condensation of chromosome and caspase-3 activity}

We observed condensed chromosome in L929 cells by using Hoechst 33342 (Thermo Fisher Scientific) staining after exposure to $\mathrm{Cr}_{2} \mathrm{O}_{3} \mathrm{NPs}$ for 12 and 24 hours. Images of condensed chromosome were captured by fluorescence microscopy (Nikon, Tokyo, Japan). Caspase-3 enzyme was quantified by using Alarifi and Ali's method. ${ }^{18}$

\section{Comet assay}

DNA damage was assessed by comet technique according to Ali et al ${ }^{12}$ method.

\section{Data analysis}

The data was presented as average \pm standard error (SE). Data were analyzed by one-way analysis of variance (ANOVA), followed by the Dunnett's test. Statistical significance was denoted as $P<0.05$.

\section{Results}

\section{Size of $\mathrm{Cr}_{2} \mathrm{O}_{3} \mathrm{NPs}$}

The size of the $\mathrm{Cr}_{2} \mathrm{O}_{3} \mathrm{NPs}$ used in this work was determined using HRTEM. Most of the nanoparticles were spherical, but some of them were polygonal. The mean diameter of the $\mathrm{Cr}_{2} \mathrm{O}_{3} \mathrm{NPs}$ was $36.8 \mathrm{~nm}$. Table 1 shows the hydrodynamic diameter and zeta potential of the $\mathrm{Cr}_{2} \mathrm{O}_{3}$ NPs in DMEM.

\section{Morphological alteration of L929 cells}

Figure 1 shows the shape and size of untreated L929 cells (Figure 1A) and cells exposed to $\mathrm{Cr}_{2} \mathrm{O}_{3} \mathrm{NPs}$ for 24 hours (Figure 1B). L929 cells became spherical and separated from the surface of the culture plates after exposure to $100 \mu \mathrm{g} / \mathrm{mL}$ of $\mathrm{Cr}_{2} \mathrm{O}_{3} \mathrm{NPs}$ (Figure 1B).

Table I DLS measurements of $\mathrm{Cr}_{2} \mathrm{O}_{3} \mathrm{NPs}$ in culture media

\begin{tabular}{ll}
\hline DLS measurements & Value \\
\hline Hydrodynamic size & $253 \pm 4.0 \mathrm{~nm}$ \\
Zeta potential & $-13.6 \mathrm{mV}$ \\
\hline
\end{tabular}

Abbreviations: $\mathrm{Cr}_{2} \mathrm{O}_{3} \mathrm{NPs}$, chromium oxide nanoparticles; DLS, dynamic light scattering. 

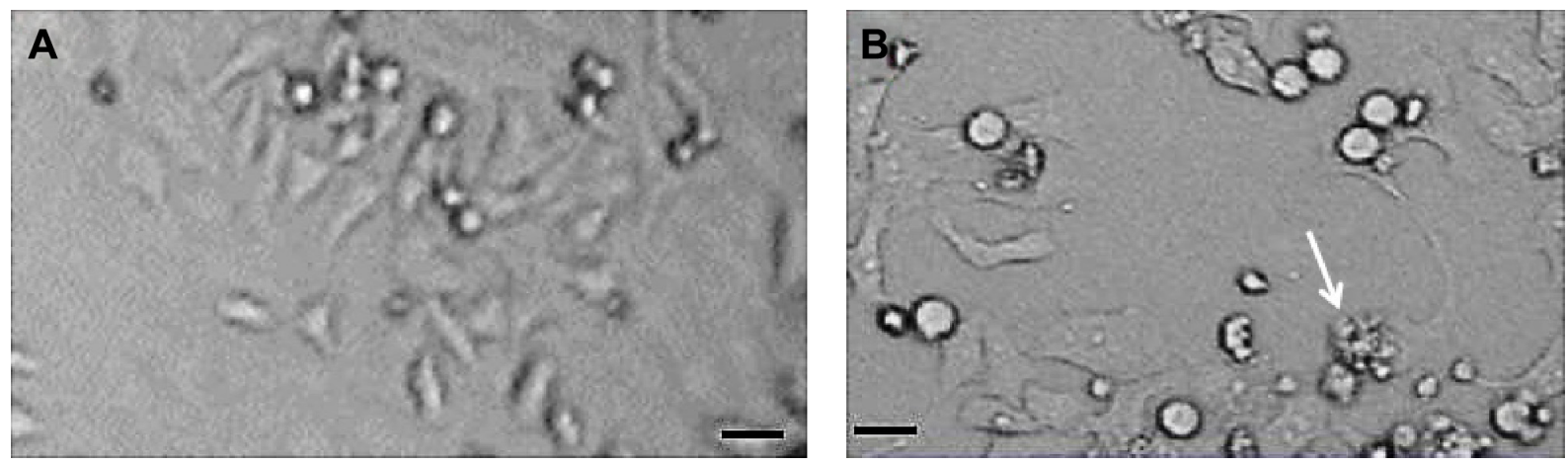

Figure I Morphology of L929 cells.

Notes: (A) Control. (B) At $50 \mu \mathrm{g} / \mathrm{mL}$ of $\mathrm{Cr}_{2} \mathrm{O}_{3} \mathrm{NPs}$ for 24 hours. Scale bar

is $50 \mu \mathrm{m}$; magnification $40 \times$. The arrow indicates a damaged cell.

Abbreviation: $\mathrm{Cr}_{2} \mathrm{O}_{3} \mathrm{NPs}$, chromium oxide nanoparticles.

\section{Cytotoxicity}

$\mathrm{Cr}_{2} \mathrm{O}_{3} \mathrm{NP}$-induced cytotoxicity in L929 cells was measured by the MTT and NRU assays. Both MTT (Figure 2A) and NRU (Figure 2B) results indicated a dose- and timedependent cytotoxicity after exposure of L929 cells to $\mathrm{Cr}_{2} \mathrm{O}_{3} \mathrm{NPs}$.

\section{Oxidative stress and production of ROS}

Induction of oxidative stress by $\mathrm{Cr}_{2} \mathrm{O}_{3} \mathrm{NPs}$ was evaluated. $\mathrm{Cr}_{2} \mathrm{O}_{3}$ NPs generated ROS in duration and concentration basis (Figure 3A-C). Due to exposure of $\mathrm{Cr}_{2} \mathrm{O}_{3} \mathrm{NP}, \mathrm{GSH}$ was decreased (Figure 4B) and LPO, SOD and catalase were increased in L929 cells (Figure 4A, C, and D).

\section{Caspase- 3 activity and condensation of chromosome}

Chromosome lesions were observed in L929 cells after treatment with $\mathrm{Cr}_{2} \mathrm{O}_{3} \mathrm{NPs}$ (Figure 5A and B). On treatment with $\mathrm{Cr}_{2} \mathrm{O}_{3} \mathrm{NPs}$, the level of caspase-3 raised (Figure 5C).

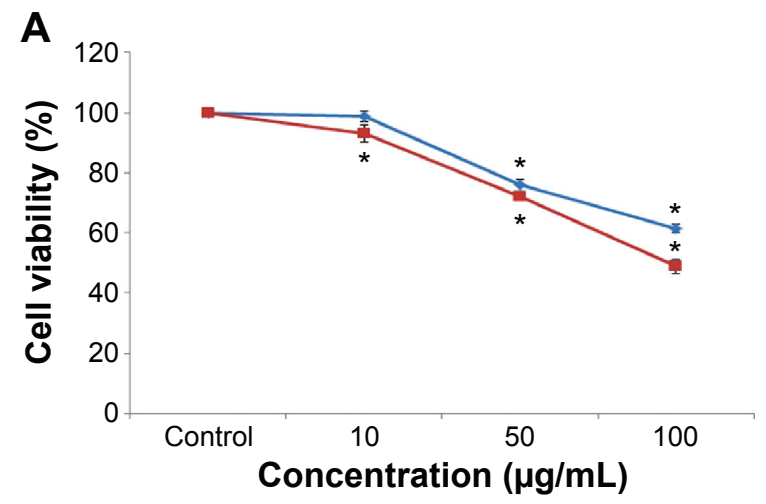

\section{DNA damage}

Damage of DNA was determined in tail DNA (\%) (Figure 6A) and Olive tail moment (Figure 6B) in untreated and $\mathrm{Cr}_{2} \mathrm{O}_{3} \mathrm{NP}$-treated L929 cells. L929 cells exhibited more DNA damage after exposure to $\mathrm{Cr}_{2} \mathrm{O}_{3} \mathrm{NPs}$ (Figure 6D) than control group (Figure 6C). Maximum level of DNA damage was recorded in L929 cells exposed to $100 \mu \mathrm{g} / \mathrm{mL}$ of $\mathrm{Cr}_{2} \mathrm{O}_{3}$ NPs for 24 hours (Figure 6).

\section{Discussion}

Metal nanoparticles are widely used in industry and medicine, but their applications have been limited because of significant toxicity and chronic secondary effects. It is the physiochemical properties of nanoparticles such as size, surface area, and structure that make them useful in nanomedicine. ${ }^{19}$ Shi and Dalal ${ }^{20}$ reported that chromium shows toxicity due to conversion of chromium(IV) to chromium(III) as a consequence of $\mathrm{OH} \cdot$ generation. Chromium(IV) crosses plasma membranes through ion channels.

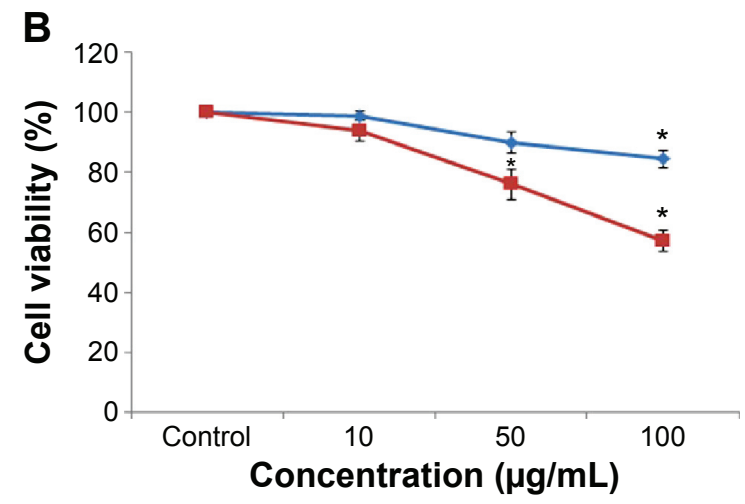

Figure 2 Cytotoxicity of $\mathrm{Cr}_{2} \mathrm{O}_{3} \mathrm{NPs}$ in $\mathrm{L} 929$ cells for 12 and 24 hours.

Notes: (A) MTT and (B) NRU tests. $* P<0.05$ vs control.

Abbreviations: $\mathrm{Cr}_{2} \mathrm{O}_{3} \mathrm{NPs}$, chromium oxide nanoparticles; MTT, 3-(4,5-dimethylthiazol-2-yl)-2,5-diphenyltetrazolium bromide; NRU, neutral red uptake; h, hours. 

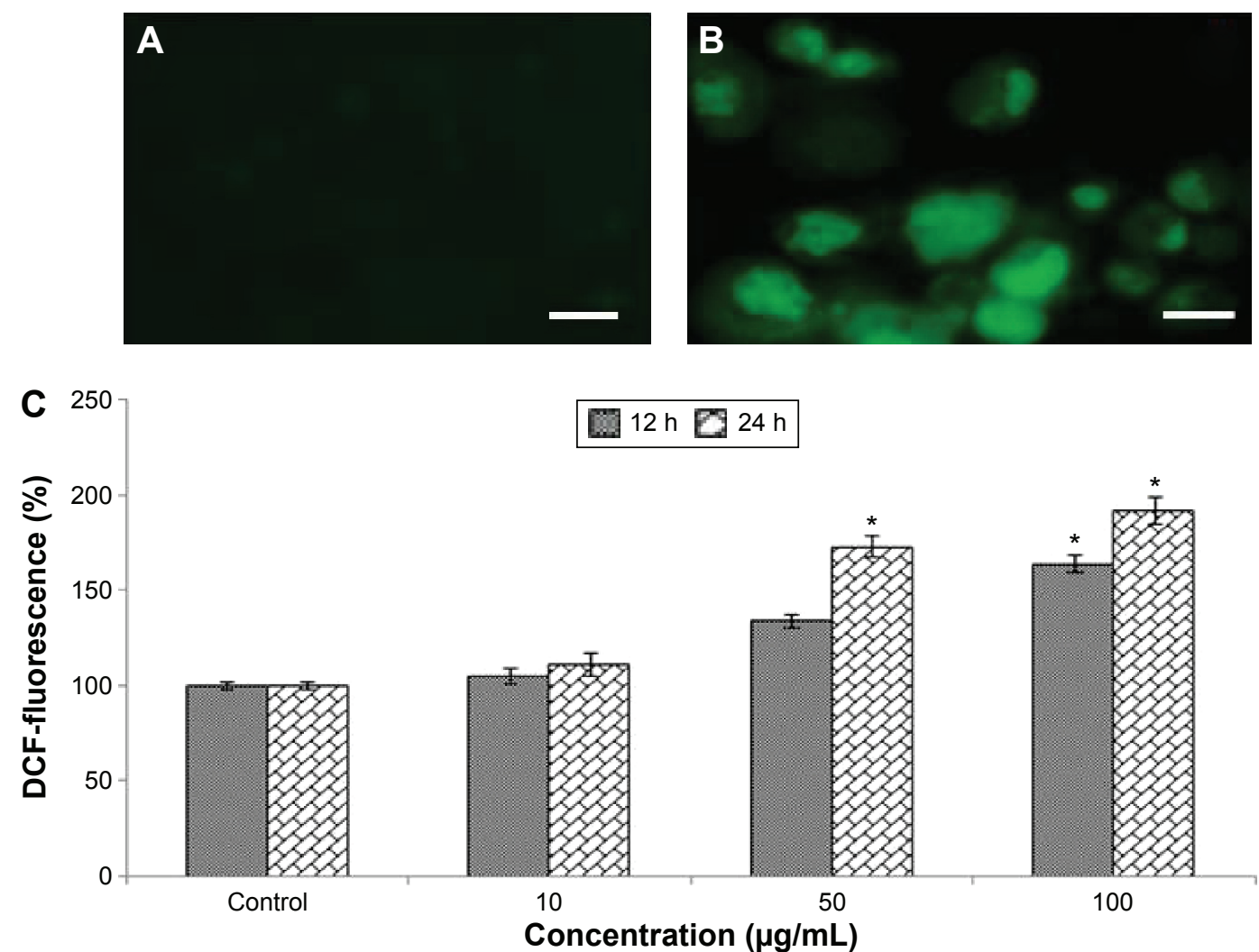

Figure $3 \mathrm{Cr}_{2} \mathrm{O}_{3} \mathrm{NPs}$ induced ROS in L929 cells.

Notes: (A) Control (B) at $100 \mu \mathrm{g} / \mathrm{mL}$ of $\mathrm{Cr}_{2} \mathrm{O}_{3} \mathrm{NPs}$ for 24 hours (C) \% ROS generation due to $\mathrm{Cr}_{2} \mathrm{O}_{3} \mathrm{NPs}$ in L929 cells. Scale bar ( $* P<0.05$ vs control.

Abbreviations: $\mathrm{Cr}_{2} \mathrm{O}_{3} \mathrm{NPs}$, chromium oxide nanoparticles; DCF, dichlorofluorescein; ROS, reactive oxygen species.

A

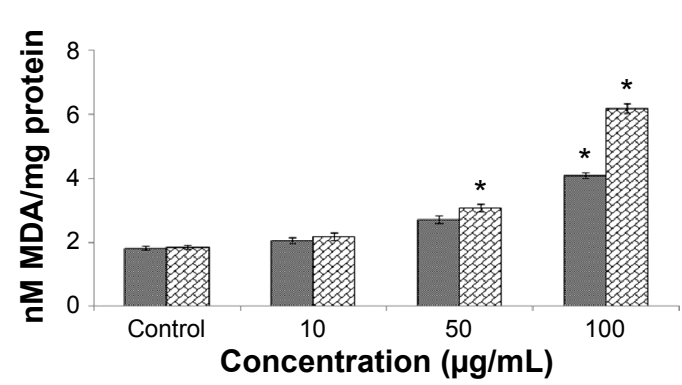

C

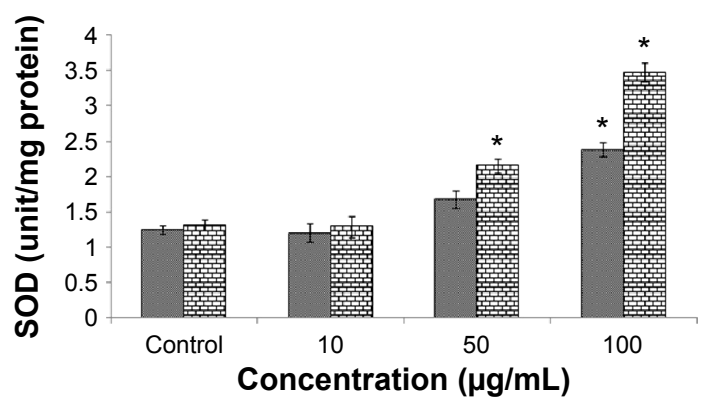

B

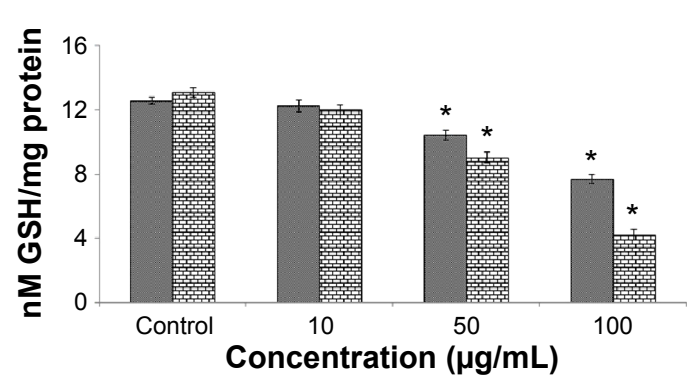

D

Concentration $(\mu \mathrm{g} / \mathrm{mL})$

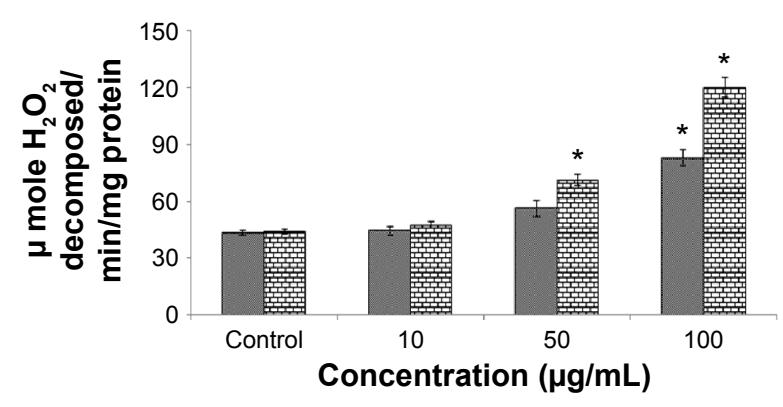

$\square 12 \mathrm{~h}$ 臣 $24 \mathrm{~h}$

Figure 4 (A) LPO, (B) GSH, (C) SOD, and (D) catalase in L929 cells after exposure to $\mathrm{Cr}_{2} \mathrm{O}_{3} \mathrm{NPs}$ for 12 and 24 hours.

Note: $* P<0.05$ vs control.

Abbreviations: $\mathrm{Cr}_{2} \mathrm{O}_{3} \mathrm{NPs}$, chromium oxide nanoparticles; GSH, glutathione; LPO, lipid peroxidation; SOD, superoxide dismutase; h, hours. 

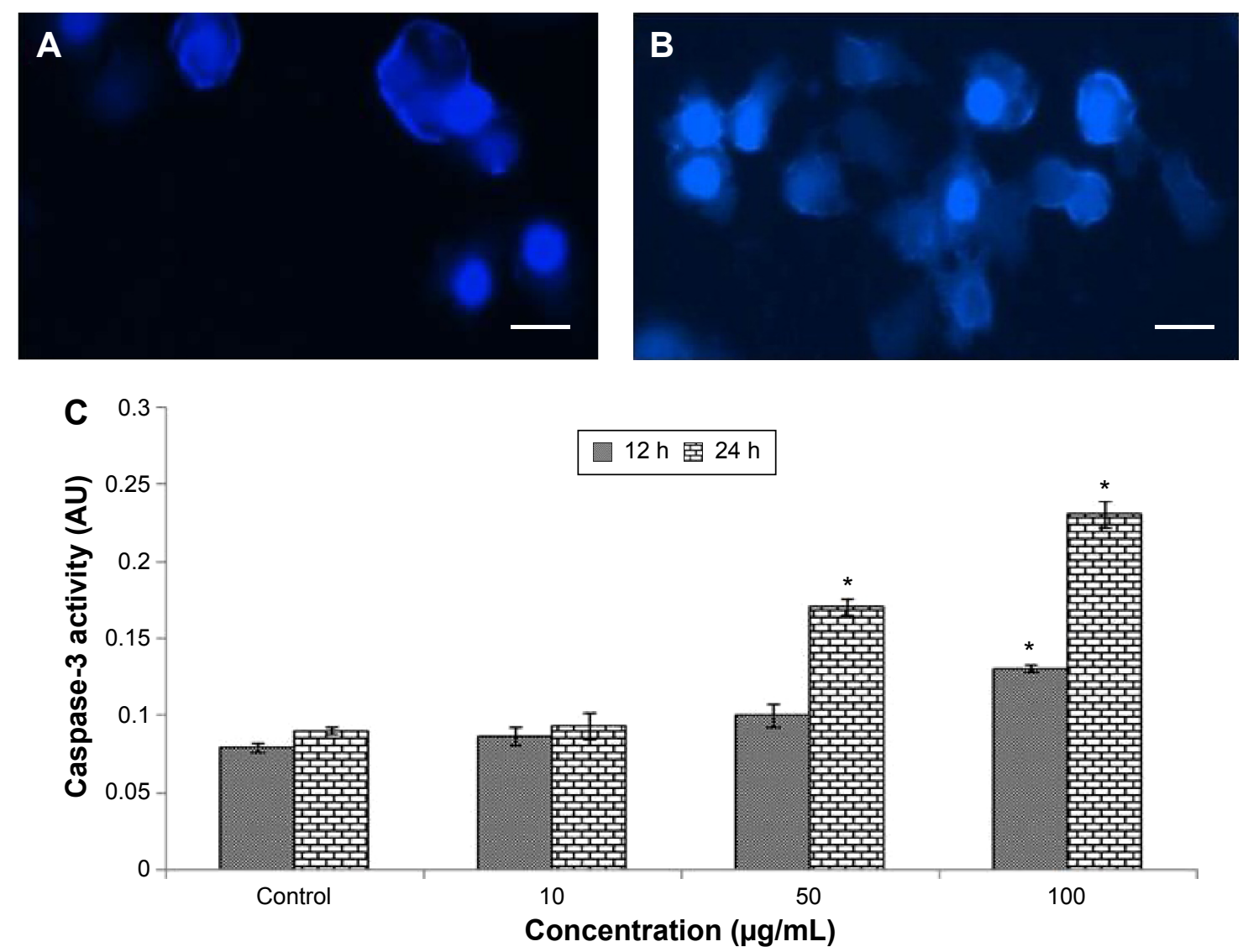

Figure 5 Chromosomal condensation and caspase-3 activity in $\mathrm{L} 929$ cells after treatment with $\mathrm{Cr}_{2} \mathrm{O}_{3} \mathrm{NPs}$.

Notes: (A) Control, (B) at $50 \mu \mathrm{g} / \mathrm{mL}$ of $\mathrm{Cr}_{2} \mathrm{O}_{3}$ NPs for 24 hours. (C) Caspase-3 activity. $* P<0.05$ vs control. Scale bar (—) $50 \mu \mathrm{m}$; magnification 40X. Abbreviations: $\mathrm{AU}$, arbitrary units; $\mathrm{Cr}_{2} \mathrm{O}_{3} \mathrm{NPs}$, chromium oxide nanoparticles; h, hours.

A

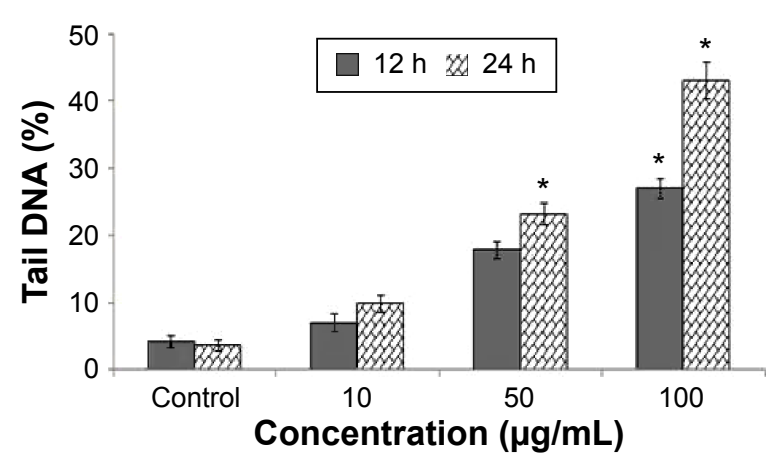

C

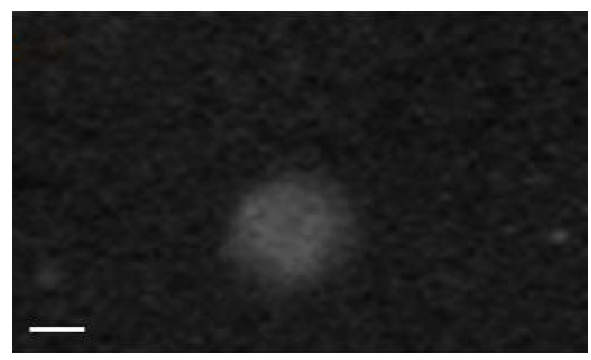

B

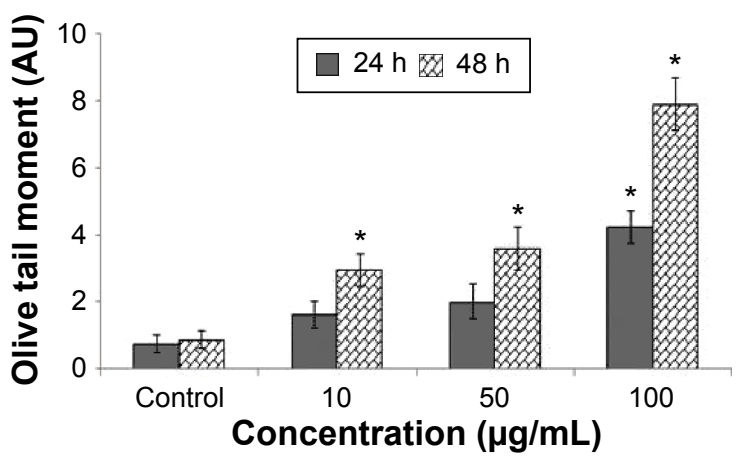

D

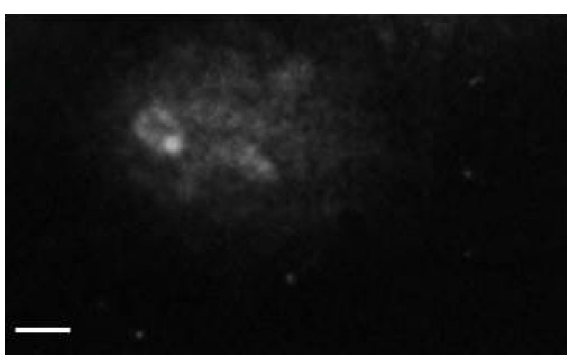

Figure 6 DNA lesions in L929 cells because of $\mathrm{Cr}_{2} \mathrm{O}_{3} \mathrm{NPs}$.

Notes: (A) Tail DNA (\%). (B) Olive tail moment. (C) Control cell. (D) At $100 \mu \mathrm{g} / \mathrm{mL}$ of $\mathrm{Cr}_{2} \mathrm{O}_{3} \mathrm{NPs}$ for 24 hours. Scale bar ( control.

Abbreviations: $\mathrm{Cr}_{2} \mathrm{O}_{3} \mathrm{NPs}$, chromium oxide nanoparticles; h, hours. 
Here, we measured the size and zeta potential of $\mathrm{Cr}_{2} \mathrm{O}_{3} \mathrm{NPs}$ by TEM and DLS, respectively, although the size determined by DLS was larger than that quantified by TEM. Our results demonstrate that toxicity of $\mathrm{Cr}_{2} \mathrm{O}_{3} \mathrm{NPs}$ in $\mathrm{L} 929$ cells was time- and dose-dependent, as measured by the cellular reduction of MTT and uptake of neutral red dye. The MTT test is a biomarker for activity of succinate dehydrogenase, a main constituent of the mitochondrial electron transport chain, and is used to measure cell survival; only live cells with undamaged mitochondria can reduce MTT dye, and the total quantity of MTT reduced is decreased in a ratio of the number of live cells. After 12 hours of exposure of cells to $\mathrm{Cr}_{2} \mathrm{O}_{3} \mathrm{NPs}$, there was relatively little effect seen in the MTT test. However, after 24 hours of treatment, significant dosedependent reduction in MTT levels were observed. The toxic effects of $\mathrm{Cr}_{2} \mathrm{O}_{3}$ NPs were validated by the observation of separation of dead cells from the surface of culture plates.

$\mathrm{Xia}$ et $\mathrm{a}^{21}$ reported that the production of ROS is a possible mechanism of $\mathrm{Cr}_{2} \mathrm{O}_{3} \mathrm{NP}$ toxicity, which might induce DNA damage. $\mathrm{Cr}_{2} \mathrm{O}_{3} \mathrm{NPs}$ were found to induce production of intracellular ROS when assessed by $\mathrm{H}_{2}$ DCFDA, thus it could be initial action for its toxic effect in $\mathrm{L} 929$ cells. $\mathrm{Cr}_{2} \mathrm{O}_{3} \mathrm{NPs}$ contain a transition metal capable of initiating Fenton reactions. The ROS-producing capability of $\mathrm{Cr}_{2} \mathrm{O}_{3} \mathrm{NPs}$ may lead to various impairments of DNA such as mutations and oxidative damage. Elevation of LPO was observed in L929 cells due to $\mathrm{Cr}_{2} \mathrm{O}_{3} \mathrm{NPs}$. GSH levels in cells declined, while catalase and SOD increased in a time- and dose-dependent manner on exposure to $\mathrm{Cr}_{2} \mathrm{O}_{3} \mathrm{NPs}$. Single-cell gel tests demonstrated significant enhancement in percentage tail DNA and Olive tail moment, both markers of DNA fragmentation, at higher doses of $\mathrm{Cr}_{2} \mathrm{O}_{3} \mathrm{NPs}$ after exposure for 24 hours.

We observed a correlation between ROS generation and fall in GSH, suggesting that greater generation of ROS induced LPO with a simultaneous decline in glutathione to hunt those free radicals. Kang et al $^{22}$ reported that oxidative stress and LPO lead to apoptosis and DNA damage. During apoptosis, a chain of biochemical reactions occurs, inducing alteration of L929 cell shape and cell death.

Kroemer et $\mathrm{al}^{23}$ reported some biomarkers to characterize apoptosis, including DNA fragmentation, cell membrane blebbing, condensation of chromosome, and shrinking and disintegration of organelles. In the present study, Hoechst 33342 (Thermo Fisher Scientific) staining of $\mathrm{Cr}_{2} \mathrm{O}_{3} \mathrm{NPs}-$ treated L929 cells indicated nuclear fragmentation and condensation. Chen et $\mathrm{al}^{24}$ reported that, because of their small size and shape, nanoparticles interact with DNA. DNA damage can either induce cell death or carcinogenesis, consequently disrupting normal cell functions. We found DNA-damaging effects of $\mathrm{Cr}_{2} \mathrm{O}_{3} \mathrm{NPs}$ in $\mathrm{L} 929$ cells by using the comet test, which identifies double- and single-strand breaks at minute damage of DNA. ${ }^{25}$

This study indicates that use of manufactured $\mathrm{Cr}_{2} \mathrm{O}_{3} \mathrm{NPs}$ should be cautiously evaluated because of its hazardous effects on animals.

\section{Acknowledgment}

The authors would like to extend their sincere appreciation to the Deanship of Scientific Research at King Saud University for its funding of this research through the Research Group Project No RGP-180. Review board approval was not sought as our institute does not require ethical committee approval for in vitro research.

\section{Disclosure}

The authors report no conflicts of interest in this work.

\section{References}

1. Gibot P, Vidal L. Original synthesis of chromium (III) oxide nanoparticles. J Eur Ceram Soc. 2010;30(4):911-915.

2. Makhlouf SA, Bakra ZH, Al-attara H, Moustafaa MS. Structural, morphological and electrical properties of $\mathrm{Cr}_{2} \mathrm{O}_{3}$ nanoparticles. Mater Sci Eng. 2013;178:337-343.

3. Pan Y, Neuss S, Leifer A, et al. Size-dependent cytotoxicity of gold nanoparticles. Small. 2007;3(11):1941-1949.

4. Zhang Y, Xu D, Li W, Yu J, Chen Yu. Effect of size, shape, and surface modification on cytotoxicity of gold nanoparticles to human HEp-2 and canine MDCK cells. J Nanomater. 2012:375496.

5. Borm PJ, Robbins D, Haubold S, et al. The potential risks of nanomaterials: a review carried out for ECETOC. Part Fibre Toxicol. 2006; $3: 11$.

6. Warheit DB, Laurence BR, Reed KL, et al. Comparative pulmonary toxicity assessment of single-wall carbon nanotubes in rats. Toxicol Sci. 2004;77:117-125.

7. Oberdorster G, Oberdorster E, Oberdorster J. Nanotoxicology: an emerging discipline evolving from studies of ultrafine particles. Environ Health Perspect. 2005;113:823-839.

8. Krewski D, Westphal M, Al-Zoughool M, Croteau MC, Andersen ME. New directions in toxicity testing. Annu Rev Public Health. 2011;32: 161-178.

9. Lin $\mathrm{W}$, Huang YW, Zhou XD, et al. In vitro toxicity of silica nanoparticles in human lung cancer cells. Toxicol Appl Pharmacol. 2006; 217:252-259.

10. Wang $\mathrm{C}, \mathrm{Hu} \mathrm{X}$, Gao Y, Ji Y. ZnO nanoparticles treatment induces apoptosis by increasing intracellular ROS levels in LTEP-a-2 Cells. Biomed Res Int. 2015;2015:423287.

11. Mossman T. Rapid colorimetric assay for cellular growth and survival: application to proliferation and cytotoxicity assays. J Immunol Methods. 1983;65:55-63.

12. Ali D, Ray RS, Hans RK. UVA-induced cyototoxicity and DNA damaging potential of benz (e) acephenanthrylene in human skin cell line. Toxicol Lett. 2010;199(2):193-200.

13. Wang H, Joseph JA. Quantifying cellular oxidative stress by dichlorofluorescein assay using micro-plate reader. Free Radic Biol Med. 1999; 27:612-616.

14. Lowry OH, Rosebrough NJ, Farr AL, Randall RJ. Protein measurement with the folin phenol reagent. J Biol Chem. 1951;193:265-275. 
15. Ohkawa H, Ohishi N, Yagi K. Assay for lipid peroxides in animal tissues by thiobarbituric acid reaction. Anal Biochem. 1979;95:351-358.

16. Alarifi S, Ali D, Verma A, Alakhtani S, Ali BA. Cytotoxicity and genotoxicity of copper oxide nanoparticles in human skin keratinocytes cells. Int J Toxicol. 2013;32(4):296-307.

17. Elman G. Tissue sulfhydryl groups. Arch Biochem Biophys. 1959;82: 70-77.

18. Alarifi S, Ali D. Mechanisms of multi-walled carbon nanotubes-induced oxidative stress and genotoxicity in mouse fibroblast cells. Int J Toxicol. 2015;34(3):258-265.

19. Donaldson K, Stone V, Tran CL, et al. Nanotoxicology. Occup Environ Med. 2004;61:727-728.

20. Shi XL, Dalal NS. Chromium (V) and hydroxyl radical formation during the glutathione reductase-catalyzed reduction of chromium (VI). Biochem Biophys Res Commun. 1989;163:627-634.
21. Xia T, Kovochich M, Liong M, Zink JI, Nel AE. Cationic polystyrene nanosphere toxicity depends on cell-specific endocytic and mitochondrial injury pathways. ACS Nano. 2007;2:85-96.

22. Kang SJ, Kim BM, Lee YJ, Chung H. Barium dioxide nanoparticles trigger p53-mediated damage response in peripheral blood lymphocytes. Environ Mol Mutagen. 2008;49:399-405.

23. Kroemer G, Petit P, Zamzami N, Vayssiere JL, Mignotte B. The biochemistry of programmed cell death. FASEB J. 1995;9:1277-1287.

24. Chen M, Mikecz A. Formation of nucleoplasmic protein aggregates impairs nuclear function in response to $\mathrm{SiO}_{2}$ nanoparticles. Exp Cell Res. 2005;305(1):51-62.

25. Collins AR. The comet assay for DNA damage and repair: principles, applications, and limitations. Mol Biotechnol. 2004;26(3):249-261.
International Journal of Nanomedicine

\section{Publish your work in this journal}

The International Journal of Nanomedicine is an international, peerreviewed journal focusing on the application of nanotechnology in diagnostics, therapeutics, and drug delivery systems throughout the biomedical field. This journal is indexed on PubMed Central, MedLine, CAS, SciSearch $\AA$, Current Contents ${ }^{\circledR} /$ Clinical Medicine,

\section{Dovepress}

Journal Citation Reports/Science Edition, EMBase, Scopus and the Elsevier Bibliographic databases. The manuscript management system is completely online and includes a very quick and fair peer-review system, which is all easy to use. Visit http://www.dovepress.com/ testimonials.php to read real quotes from published authors.

Submit your manuscript here: http://www.dovepress.com/international-journal-of-nanomedicine-journal 